\title{
腎細胞癌の脳転移
}

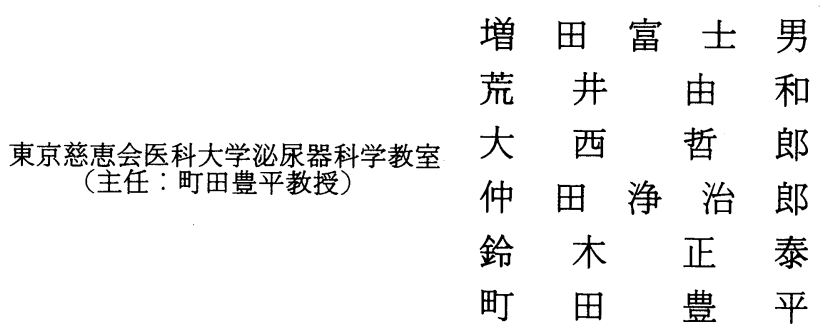

\section{BRAIN METASTASIS FROM RENAL CELL CARCINOMA}

\author{
Fujio Masuda, Yoshikazu Arai, Tetsuro Ohnishi, Jyojiro Nakada, \\ Masayasu Suzuki and Toyohei Machida \\ Department of Urology, The Jikei University School of Medicine, Tokyo
}

(Director: Prof. T. Machida)

Out of 112 patients with renal cell carcinoma, seen in the Jikei University Hospital during the 11year period from July 1973 through June 1983, 9 (8.0\%) exhibited brain metastasis. The examination of the afflicted side of the primary focus revealed the brain metastasis in 6 of 63 patients $(9.5 \%)$ in the case of the left renal carcinoma, and in 3 of 48 patients $(6.3 \%)$ in the case of the right.

There was thus a tendency for the brain metastasis to occur more easily in the left than in the right renal cancer. As for the time of the metastasis discovery, it was already at the time of initial diagnosis in 2 cases, and in the other 7, it was after nephrectomy. The average interval between the operation and metastasis discovery was 3 years, and in 4 of the 7 cases $(57 \%)$, over 3 years had passed in between. Seven of the 9 cases were complicated by pulmonary metastasis, and it was considered most frequent that the brain metastasis occurred by the route through the pulmonary metastatic focus. As for the symptom of brain metastasis, dyskinesia was most frequent, being seen in 5 cases ( $56 \%$ ), followed by headache, nausea, lalopathy, dysopia and dusuria. As for the diagnostic method, CT scanning was most effective, and as for the treatment, 4 of the 9 cases were subjected to operation with the highest efficacy. But radiotherapy and chemotherapy, performed on 4 cases, were without effect. One-year survival rate for the 9 cases was $22 \%$, and the interval between the diagnosis of brain metastasis and death for the 7 dead cases ranged 2 months to 4 years and 6 months, with the mean of 11.4 months. The time of diagnosis and the method of therapy were recognised as the factors influencing the prognosis of brain metastasis.

\footnotetext{
要旨：1973年 7 月から 1983 年 6 月までの 11 年間に, 慈恵大学病院で診療した腎細胞癌 112 例中 9 例, $8.0 \%$ に脳転移をみとめた。原発巣の患側をみると, 左腎細胞癌では63例中 6 例, $9.5 \%$, 右腎細胞癌では 48 例 中 3 例, $6.3 \%$ に脳転移が生じており, 左腎細胞癌は右腎細胞癌に比べて, 脳転移を生じ易い傾向がみら れた。脳転移が診断された時期をみると, 初診時すでに脳転移のみとめられたのは 2 例であった。のこ りの 7 例は腎摘除後に診断されており, その平均間隔は 3 年で, 7 例中 4 例, $57 \%$ は術後 3 年以上経過 していた。 9 例中 7 例は肺転移を合併しており, 腎細胞癌の脳転移は, 肺転移巣より転移する経路が最 も多いと考えられた。症状は運動障害が 5 例, $56 \%$ と最も多く, ついで頭痛, 呕気, 言語障害, 視力障 害, 排尿障害がみられ, 診断法としてはCT スキャンが最も有用であった。治療法としては, 9 例中 4 例に手術を行い, 最もよい効果がえられたが, 放射線療法や化学療法を行った 4 例に, 有効例はみられ なかった。 9 例の 1 年生存率は $22 \%$ であ, 死亡した 7 例の脳転移診断から死亡までの期間は, 2 カ月
} 
〜 4 年 6 カ月, 平均 11.4 カ月であった. 予後に関与する因子として, 脳転移の診断時期と治療法がみと められた。

\section{緒言}

悪性腫瘍は, 転移の有無およびその治療が予後に重 大な影響を与える。腎細胞癌は剖検時には $95 \%$ に転移 が存在する1)といわれて抢り, 他臟器の腫瘍に比べて 転移は高頻度にみられる。腎細胞癌の脳への転移は肺, 骨，肝などに比べて少ないが，決して稀ではない。し かし腎細胞癌の脳転移に関する報告は少なく，しかも 大部分は剖検例についての検討であり，臨床例につい ての分析はほとんどなされていない。

われわれは腎細胞癌の脳転移について，自験例の臨 床的な検討を行ったので報告する。

\section{対象症例}

1973年 7 月から1983年 6 月までに, 慈恵大学附属病 院で診療した腎細胞癌患者中, 臨床的に脳転移を有す ると診断された 9 例について，臨床的検討を行った。

\section{成 績}

1. 脳転移の頻度, 年齢, 性別

1973年 7 月より 1983年 6 月までの 11 年間に，慈恵大 学附属病院で診療した腎細胞癌は112例で,脳転移は 9 例， $8.0 \%$ にみられた。

9 例が腎細胞癌とはじめて診断されたときの年齢は $40 \sim 62$ 歳，平均 54.6 歳で，性別は男性 8 例，女性 1 例 であった。

\section{2. 原発巣の病理}

原発巣の患側は左 6 例，右 3 例であった。原発巣の 患側と脳転移との関係をみると，左腎細胞癌では63例 中 6 例，9.5\%，右腎細胞癌では 48 例中 3 例， $6.3 \%$ に 脳転移がみられて打り，左腎細胞癌は右腎細胞癌に比 べて，脳転移を生ずる頻度が高い傾向がみられた。

初診時に打ける原発巣の stage を，Robsonの分類 でみると, stage 1 が 2 例, stage $2 か ゙ ~ 2$ 例, stage $3 \mathrm{~A}$ が 1 例， stage $3 \mathrm{~B}$ が 1 例， stage $4 \mathrm{~B}$ が 3 例であった。 また細胞の悪性度についてみると, grade $1 か ゙ 1$ 例, grade 2 か 1 例, grade 3 が 5 例, grade 4 が 2 例であっ た. Low stage (stage 1岾よび stage 2) 4 例の grade をみると，3例が high grade (grade $3 お$ よび grade 4) であり, stage に比べて細胞学的悪性度は高い傾向が みられた。

\section{3. 脳転移の診断時期}

9 例中, 初診時すでに脳転移をみとめたものは 2 例 で, 腎細胞癌112例中1.8\%であった。
図 1 脳転移の診断時期

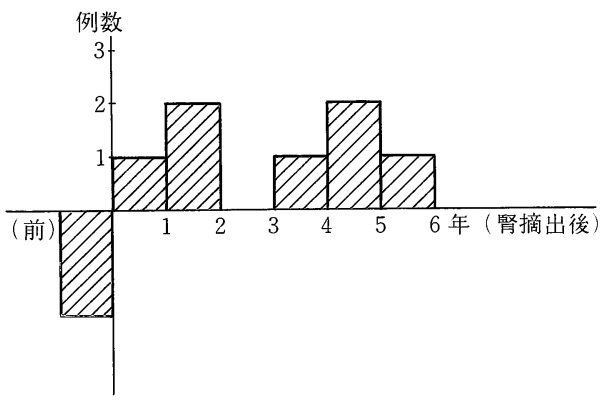

腎摘出後に脳転移が生じたものは 7 例で, 腎摘除か ら脳転移診断までの期間は， 1 年以内 1 例， $1 \sim 2$ 年 2 例, $3 \sim 4$ 年 1 例, $4 \sim 5$ 年 2 例, $5 \sim 6$ 年 1 例で, その平均期間は 3 年であったが， 7 例中 4 例（57\%） と過半数は, 腎摘除後 3 年以上経過してから転移がみ とめられている(図 1).

\section{4. 肺転移との関係}

9 例のうち 7 例 (78\%) は肺転移も伴っていた. 7 例中 1 例は, 肺転移と同時に脳転移が診断されたが, 5 例は肺転移に対する治療後 3 力月 4 年 2 月, 平均 1 年 7 月後に脳転移がみとめられている。また 1 例は, 脳転移に対する治療後 4 力月目に肺転移がはじめて診 断された。

肺転移がみとめられなかったものは 2 例で，このう ちの 1 例は胸椎への転移を伴っていたが，他の 1 例は 脳転移のみで，他臟器への転移はみられなかった。

5 . 症状

9 例の脳転移による臨床症状を検討した結果は表 1 に示した。運動障害が 5 例（56\%）と最も多く，つい で頭痛 3 例 (33\%), 呕気 2 例 (22\%), 言語障害, 視 力障害, 排尿障害が各 1 例（11\%）にみられた。

表 1 脳転移の症状

\begin{tabular}{c|c}
\hline 症 状 & 例 数 \\
\hline 運動障害 & 5 \\
頭 痛 & 3 \\
呕 気 & 2 \\
言語障害 & 1 \\
視力障害 & 1 \\
排尿障害 & 1 \\
\hline
\end{tabular}


表 2 脳転移の診断法

\begin{tabular}{l|c}
\hline \multicolumn{1}{c|}{ 診断法 } & 例 数 \\
\hline 臨床症状 & 9 \\
CTscan & 6 \\
Angiography & 2 \\
脳 scintigram & 1 \\
\hline
\end{tabular}

すなわち局所症状としては運動障害が最も多く, 脳 圧六進症状としては頭痛が最も多くみられた。

\section{6. 診断}

脳転移の診断に用いられた検査法は表 2 のごとくで ある.脳血管撮影は 2 例, 脳シンチグラムは 1 例に行 われているが，いずれも比較的古い症例であり，最近 の 6 例はすべて CT スキャンを行い，転移とともにそ の部位が診断された。

6 例の CT スキャンでは, 腫瘍本体とともに, 腫瘍 の周辺を中心とする浮腫が, low density としてみとめ られている（図 2，3）。

7. 治療

治療は手術が 4 例に行われた。いずれも単発で, 原 発巣の腎は摘除され, 肺転移もないか, あってもよく コントロールされた例であった。 4 例は術後いずれも 神経症状は改善され，2 例は死亡したものの術後 1 年 および 4 年 6 力月間生存し, のこりの 2 例も術後 5 力 月目の現在生存中である。

放射線療法は 1 例に行った. Linac の照射を 1 日200 rads 施行したが， 8 日間合計1,600rads 照射した時点 で，一般状態が不良となり中止した。

化学療法は 3 例に施行した. 2 例に mitomycin C, 5-

図 2 症例 8 の CT 像: 腫瘍病変と, その周辺に脳浮 腫を示す低吸収域がみられる。

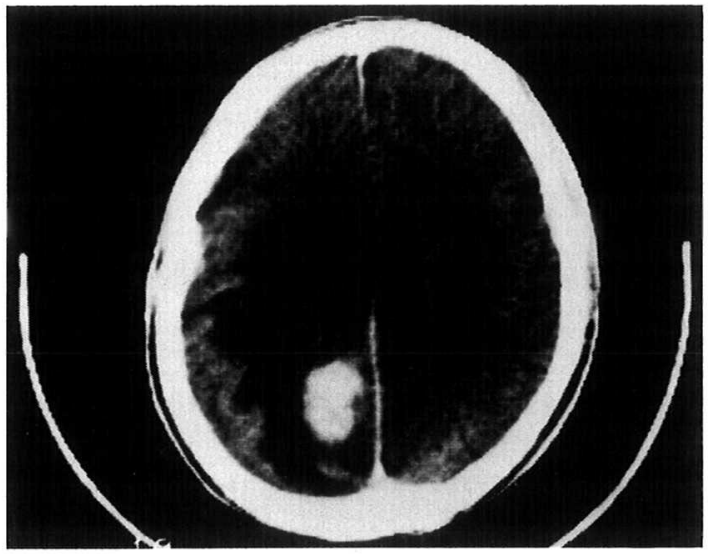

図 3 症例 9 の CT 像：多発性の腫瘍病変と, その周 辺の脳浮腫がみられる。

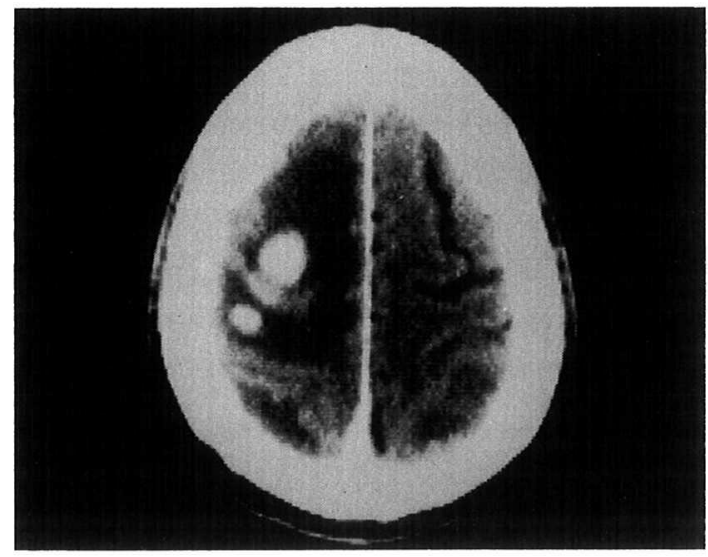

fluorouracil, cytosine arabinoside の併用療法を行 い，1例に UFT を投与したが，有効例は兄られなかっ た. UFTを投与した 1 例は，1 日600 $\mathrm{mg}$ を73日間，合 計 $43.8 \mathrm{~g}$ 投与したが, その前後の CT スキャンで, 後頭 頂部にみられた腫瘍は $3.7 \times 3.3 \mathrm{~cm}$ から $4.3 \times 3.3 \mathrm{~cm}$ となり, 縮小はみられなかった。しかし自覚症状のけ いれん, 運動障害は一時的ではあるが軽快をみている。

8. 予後

9 例中, 死亡した症例は 7 例で, 脳転移診断から死 亡までの期間は 2 力月 4 年 6 力月, 平均 11.4 力月で あった。とくに初診時すでに脳転移のみられた 2 例は， いずれも 2 カ月以内に死亡しており，予後ははなはだ 不良であった。一方, 現在生存中の症例は 2 例で, 脳 転移診断後の生存期間は, いずれも 5 力月である。す なわち, 脳転移例の 1 年生存率は 9 例中 2 例, $22 \%$ で あった。

治療別に予後をみると，手術を行った 4 例中 2 例は 術後 5 力月の現在生存中であり, 他の 2 例も死亡した ものの, 術後 1 年㐨よび 4 年 6 力月生存している。こ れに対して, 化学療法および放射線療法を行った 5 例 は, すべて 6 カ月以内に死亡している。

\section{考察}

腎細胞癌の転移は肺が最も多く, ついでリンパ節, 肝, 骨の順にみられる ${ }^{1)}$.しかし脳転移も決して稀では なく，剖検例では5.7 9.7\% ${ }^{1) ~ 3)}$ とみとめられている。 臨床例では, Riches ${ }^{4}$ が562例中30例, 5.7\%にみられた といい，われわれも112例中 9 例，8.0\%に脳転移をみ とめた。

原発巣の患側をみると, 左腎は右腎よりも脳転移を 
生ずる頻度が高い傾向がみられた.この一因としては, 左腎が右腎に比べて豊富な側副血行を有するため, 血 行性転移が生じ易いと考兄られる。亦た剖検例の検討 で, 脳転移が, 非腎摘除例に明らかに多くみられる ${ }^{3)}$ とを併せ考学ると, 手術よりも腎摘除例操作による腫 瘍撒布の可能性が示唆される。

腎摘除より脳転移がみとめられるをでの期間は長 く, 7 例中 4 例 (57\%) が 3 年以上であった。この点， 肺転移 19 例中 17 例, $89.5 \%{ }^{5)}$, 骨転移 7 例中 5 例, $\left.71.4 \%{ }^{6}\right)$ が，いずれも術後 2 年以内に転移を生じてい るのと対称的である，このことは, 脳転移が肺転移巣 や骨転移巣から生じていることを示唆しているものと 考えられ, 転移経路の問題とも関連して興味深い。

転移経過を示すいま 1 つの事実は, 脳転移例 9 例中 7 例が肺転移を，1例が骨転移を伴っていたことであ ク，また 1 例は脳以外に転移をみとめなかったことで ある.すなわち腎細胞癌が脳へ転移する経路としては, 次の 3 経路が考学られる. 第 1 は腎静脈から下大静脈 の経路, あるいは所属リンパ節から胸管, 上大静脈の 経路を通り, 右心を経て肺へ転移巣を生じたのち, 全 身の動脈系循環に入り, 脳へ転移するものである、第 2 は傍脊椎静脈 (Batson 静脈叢)をへて骨に転移する とともに, 直接脳へ転移するものであり, 第 3 は第 1 の経路で肺に達した腫崵細胞が、肺に転移を生ずるこ となく, 単一細胞をたは小血栓として肺の毛細管を通 過して全身の動脈系循環に入り, 脳へ転移するもので ある。肺転移を伴うものが 7 例及られたことは，第 1 の経路が最も一般的であることを示し, 胸椎転移合併 例は第 2 の経路を, 脳のみの転移例は第 3 の経路によ ることを示しているといえよう。

$\mathrm{Nisce}^{7)}$ は560例の転移性脳腫瘍の症状について検討 した結果, 運動障害が $75 \%$ と最も多く, ついで意識障 害 $41 \%$, 頭痛 $33 \%$, 知覚障害 $28 \%$, 言語障害 $15 \%$, 複 視14\%, めむい $8 \%$ \%ったといらが, 自験例でも運 動障害が最も多く, ついで頭痛がみられた。勿論これ らの症状は脳血管障害でもみられるが, 腫瘍転移例で は一般に発症がより緩徐であり，より進行的である。 しかし脳転移でも，あたかも脳血管障害を思わせるよ らに，突然に神経症状が発現することも少なくないの で, 注意を要する。したがって腎細胞癌の既往があり, これに上記のような症状があらわれれば，まず脳転移 を考えて検索をすべきであろう。

診断法は, これまで臨床症状をもとに, 脳血管撮影, 脳ンンチグラムが行われてきたが，最近はCTスキャ
ンにより，比較的簡単且つ容易に転移が診断されるよ らになった。自験例でも最近の 6 例は, すべてCT ス キャンで診断されており，CTスキャンは脳転移の診 断上，不可欠の検査法となっている.

治療は, 脳浮腫に対して副腎皮質ホルモンを投与し, 脳圧元進に対しグリセオールやマニトールの静注を施 行するとともに, 手術療法, 放射線療法, 化学療法が 行われる。手術療法の適応は, 単発性転移で, しかも 摘出により神経学的な機能障害をさたさない部位であ り，かつ原疾患が十分にコントロールされて，ある程 度, 少く子も数力月間の生存が期待できる例であり, 自験例でもこのような 4 例に手術を行った。

放射線療法は 1 例しか施行しなかったが，一般に脳 転移に対しては比較的よい成績を示すといわれてお り, 多発性転移や摘出不能例の治療としては最もすぐ れて扮り ${ }^{8)}$, さらに手術や化学療法との併用も行われ ている.

化学療法の効果は自験例ではみられなかった。脳転 移に対して化学療法を行らに際しては, 血液脳関門の 存在を考慮しなければならない。この関門を通過する 薬剤としては, $\mathrm{ACNU}, \mathrm{BCNU}, \mathrm{CCNU} と ゙ の$ nitrosourea 系化合物や，5-FU の masked compound である FTがある。われわれも 1 例に, FT と uracil の 合剂であるUFTを投与したが，効果をえられなかっ た、今後さらに検討を加えていきたい。

自験例の 1 年生存率は $22 \%$ であったが，予後をきめ る因子の 1 つは転移の生じた時期で, 初診時すでに転 移のみられた例は，腎摘除後に生じたものより予後は 不良であった。いま1つは治療法で, 手術が施行され た例は, 放射線療法や化学療法を行ったものよりもよ い治療成績であったが, Khoury9) るこ 2 点について 同様の成績をのべている，また Winston ${ }^{10)}$ は腎細胞癌 の脳転移に手術を行った 9 例の 1 年生存率は $27 \%, 2$ 年生存率は $22 \%$ であり, 肺, 骨, 皮痛など他臓器から の転移よりも長い生存期間が党られたといっているこ とから, 腎細胞癌の脳転移に対しては, 積極的な治療 がのぞまれる。ささらに本症の予後で大切なことは，た 几に生存期間のみでなく, 治療により生活能力の改善, 神経症状, 機能障害の改善が党られることであり, 手 術を行った 4 例は, いずれも脳転移による症状の改善 がみられている。将来の問題としては, 脳転移の早期 発見があげられる。われわれは腎細胞癌の局所再発の 診断に，術後定期的に腹部 CT スキャンを行い，その 有用性をみとめている(11) 脳転移に対しても定期的 
に脳の CT スキャンを行い，無昰状の転移を発見し， 早期に治療を施行したいと考えている。

\section{結語}

腎細胞癌の脳転移，9症例について臨床的検討を 行った。

1. 腎細胞癌の脳転移の頻度は, 112 例中 9 例, $8.0 \%$ であった。

2. 原発巣の患側㹥左側 6 例, 右側 3 例で, 左腎細胞 癌に脳転移が生じ易い傾问がみられた。

3. 脳転移の診断時期は, 初診時すでにみられた 2 例 をのぞき，腎摘除後に生じた 7 例の平均期間は 3 年々 長く，そのうちの 4 例 (57\%) は術後 3 年以上経過し ていた。

4. 9 例中 7 例は肺転移を伴っており,肺転移嗠より 脳へ転移する経路が，最も一般的な転移経路と考えら れた。

5. 症状は, 運動障害を第 1 とする局所症状と, 頭痛 をはじめとする脳圧元進症状がみとめられた。

6. 診断法としては, CT スキャンが最近の6 例すべ てに行われ，腫瘍本体とともに周辺の浮腫がみとめら れ，診断上もっとも有用であった。

7. 治療としては，9例中 4 例に手術が行われ，最も よい治療効果がえられたが，放射線療法や化学療法を 施行した 4 例に，有効例はみられなかった。

8. 9 例の 1 年生率は $22 \%$ であったが, 脳転移の診断 時期，治療法が予後に関与していた。

\section{文献}

1) Bennington, J.L. and Beckwith, J.B.: Tumors of Kidney, Renal Pelvis, and Ureter, p. 168,
AFIP, Washington, D.C., 1975.

2）大越正秋, 長谷川昭：腎腺癌の臨床病理学的検討. 日泌尿会誌，59，1105-1116，1968.

3) Saitoh, H., Shimbo, T., Tasaka, T., Iida, T. and Hara, K. : Brain metastasis of renal adenocarcinoma. Tokai, J. Expl Clin. Med., 7, 337-343, 1982.

4) Riches, E.W., Griffiths, I.H. and Thackray, A. C. : New growth of the kidney and ureter. Br. J. Urol., 23, 297-356, 1951.

5）増田富士男, 町田豊平, 木戸 晃, 田代和也：腎細 胞癌の肺転移. 日泌尿会誌, 70,668一-677, 1979.

6）佐々木忠正，柳沢宗利，鈴木博雄，增田富士町，小 路 良：腎細胞癌の骨転移。医療，34，895-902, 1980.

7) Nisce, L.Z., Hilaris, B.S. and Chu, F.C.H.: A review of expreience with irradiation of brain metastasis. Am. J. Roentgenol., 111, 329-333, 1971.

8）野村和弘, 涉井壮一郎, 三木啓全, 高倉着明：転移 性脳腫瘍の集学的治療. 癌と化学療法, 8, 1867-1877, 1981.

9) Khoury, S. : The treatment of metastasis from renal cell carcinoma. Prog. Clin. Biol. Res., 100, 541-547, 1982

10) Winston, K.R., Walsh, J.W. and Fisher, E.G.: Results of operative treatment of intracranial metastatic tumors. Cancer, 45, 2639-2645, 1980 .

11）増田富土男, 陳 瑞昌, 仲田浄治郎, 大西哲郎, 町 田豊平, 菱沼秀雄: 腎腫瘍摘出後の Computed Tomogeaph による検討. 日泌尿会誌, 72, $1238^{--1244,} 1981$.

（1983年 7 月17日受付） 